\title{
Star Search: Do Elections Help Nondemocratic Regimes Identify New Leaders?
}

\author{
Edmund Malesky and Paul Schuler
}

A commonly proffered theory to explain the use of elections in authoritarian regimes is that they help identify talented young leaders who can be groomed for leadership positions. Unfortunately, due to the difficulties of obtaining data in authoritarian settings, this hypothesis has not been tested satisfactorily. We examine candidate-level data from the 2007 Vietnamese National Assembly (VNA) election and subsequent selection of candidates for top positions within the VNA and for top ministry positions. We find no evidence that vote share is associated with promotion to leadership positions in the VNA and only limited evidence for vote share association with ministerial posts. Instead, the results indicate that leadership selection takes place within the party rather than through elections. Furthermore, behavior within the assembly suggests that those who were chosen may have been selected based on their loyalty or at least pliancy to the party elites. Kerwords: Vietnam, elections, authoritarian, co-optation, National Assembly, talent selection, political development, electoral competitiveness, loyalty, party strength

IN AN EFFORT TO STEM CORRUPTION AND STRENGTHEN THE BOND BEtween the state and its citizens, Vietnamese officials, scholars, and reform advocates have called for an increased role for the National Assembly (VNA) in lawmaking and oversight of the state. Although the ruling Vietnam Communist Party (VCP) has not moved as quickly or deeply as some critics inside the country would like, they have strengthened the role of the institution in recent years. Since the passage of the 1992 constitution, the VNA has more full-time delegates and electoral competition has been widened, so that in 2007 there were at least two more candidates than seats in each election district. The VNA has also increased its visibility by holding two instead of one session per year and by holding nationally televised query sessions (chất vấn). 
However, those who support the VNA's enhanced role, particularly reform-minded officials in the Office of the National Assembly (ONA) tasked with running the assembly's ten standing committees, are concerned about a deficiency of expertise and competence within the VNA. ${ }^{1}$ Indeed, because of its history as a rubber-stamp assembly comprising mainly part-time delegates for whom a position in the VNA is either a duty or a reward for loyal service to the party, the body has largely been viewed as incapable of dealing with complex tasks. Recognizing this lack of capacity, international donors have worked with the ONA for more than a decade to improve the quality of delegates through programs such as a cooperation project with the Swedish Riksdag in the early 2000s and an ongoing $\$ 7.5$ million project with the United Nations Development Programme (UNDP) to improve democratic institutions.

Party intellectuals have debated whether increasing competition, even in single-party elections, can improve delegate quality. In 2010, the Vietnamese Journal of Legislative Studies (Tap Chi Nghiên Cúu Lâp Pháp) featured a relatively open exchange on how to amend the election law in preparation for the 2011 VNA elections. Chief among those debates was whether to legislate education standards for delegates or to allow candidates to self-nominate freely as long as they are not members of an opposition party. Supporters of education requirements contend that legislating standards is necessary to ensure a minimal level of quality for delegates, while opponents argue that more liberalized elections and relaxed vetting processes will elicit better performance by allowing voters to choose representatives that more closely reflect their preferences.

This dialogue is situated within a broader debate among students of Vietnam and authoritarian regimes regarding the purpose elections serve in single-party systems. Theories abound about the potential benefits a regime may gain from elections, ranging from increased domestic and international legitimacy to information about potential opponents. We use data from the 2007 election to test one of the theories explaining the benefits of competitive elections in democracies (Fearon 1999) and autocracies (Geddes 2006) - that states actually use elections to identify competent candidates or to improve the performance of existing delegates. This explanation echoes a more general argument that authoritarian regimes hold elections so that citizens can identify the most important and competent local leaders, whom the regime leaders will then incorporate into the ruling elite (Boix and Svolik 2007). 
We argue that the VCP does not use the elections as the primary mechanism for (1) identifying talented politicians or (2) inducing candidates to improve performance by making them accountable to their constituents. This is not to say that the VCP does not value highly competent delegates. Rather, our study shows that the VCP uses its own internal procedures - not elections - for assessing who is qualified and who is not. We base our argument on an analysis of how the regime chooses leaders in the assembly and in the government after the election.

Given the extreme hierarchy within the VNA, the selection of committee chairs and members of the VNA Standing Committee is of particular importance, as these delegates wield a disproportionate level of influence within the assembly relative to the part-time members (Harrington, McDorman, and Neilson 1998). ${ }^{2}$ If the regime is concerned about the quality of the assembly, these full-time delegates, who remain in Hanoi all year and play a crucial role in drafting legislation, are precisely those who should demonstrate the highest level of competence. Therefore, if elections are used to identify and empower qualified "rising stars," candidates with a strong performance in the elections should be the ones assigned to leadership positions.

Nevertheless, our analysis shows that the criteria the regime uses for selecting leaders in the assembly are based on how the candidates were nominated rather than on how they performed in the election. Candidates for the VNA are nominated in two ways. More than 150 are nominated and vetted by central party and state agencies and then sent to compete in the provinces. The remaining 700 candidates are nominated at the provincial level. Candidates who were nominated by the central institutions received the leadership positions regardless of their relative performance in the election, where they were elected, or their personal background, which shows that the decisions about which delegates are best suited to assume leadership roles are made well before the citizenry weighs in.

In contrast to the selection of VNA leaders, we do find some evidence that election results may play a limited role in the selection of government ministers, though the ministers too were exclusively limited to centrally nominated candidates. Among the roughly 150 candidates, those who were selected as ministers did perform somewhat better electorally than other central nominees. However, despite the modest role popularity may have played in selection, we must reiterate that the regime did limit ministerial positions only to those who 
underwent the central vetting process. Thus, election results played, at best, a secondary role to internal decisionmaking processes.

Finding that the party uses internal methods rather than elections to select leaders naturally leads to the question of what criteria the party uses to choose its leaders. According to the logic of opponents of liberalization, the regime relies on internal methods because it believes doing so will deliver higher quality candidates, which would suggest that the regime bases its decisions on technical competence or educational qualifications. However, other theories of single-party government suggest that factionalism (Shih, Adolph, and Liu 2012) or loyalty (Reuter and Turovsky 2011) could be more important. Unfortunately, in terms of selection to the VNA we cannot directly address this question, as we do not have a comprehensive list of the entire pool of candidates for central nomination as well as their past records on support for the party. However, we can indirectly address the question of whether loyalty may have played a role in their selection based on the behavior of the leadership after they were vetted and elected to the VNA. Using data collected from participation in query sessions between 2007 and 2011, we find that the leaders who were eventually selected spoke far less and far less critically than other comparable delegates. This suggests that loyalty, or at least pliancy, to the central party played a role in their selection.

Our findings are as follows. First, we examine the debate surrounding the question of how to improve the performance of the VNA, with a particular focus on the theory of using elections to improve candidate quality. Second, we identify theories of democratic elections relevant to Vietnam. Third, we discuss the structure of the VNA and develop hypotheses that would support the theory of elections presented above. Fourth, we analyze a set of delegate-level data to assess whether the VCP rewards candidates who perform well in elections with important leadership positions in the VNA. Fifth, we provide a series of tests to determine whether loyalty may be a factor in choosing the leadership. We then conclude with a discussion of alternative theories for Vietnamese elections, with a particular focus on the informational and legitimacy benefits the regime may receive through conducting relatively open elections.

\section{Improving the Quality of the \\ Vietnamese National Assembly}

Both proponents and critics of the way the VNA is currently selected cite the passage in the Vietnamese constitution that declares the 
Vietnamese state should be "by the people, for the people, and of the people" to support their arguments. The VNA, as a directly elected body meant to oversee the state, is the conduit through which this principle is realized (Nguyễn Đăng Dung 2007, 656). Although this has always been the party's official position on the VNA, in recent years there have been indications that the VCP wants to change that position from a mere slogan to a reality. In addition to televising VNA activities and increasing the number of full-time delegates, the VCP has also steadily armed the VNA with more concrete powers with each successive wave of constitutional revisions and with amendments to the law governing the operation of the VNA, which have expanded the number of permanent committees on the body. The VNA has been granted the power to vote on no-confidence measures for government ministers and to oversee some portions of budget allocation (Vietnam Development Report 2010). It has also become more involved in drafting legislation with government legal committees, and in some cases has actually amended pieces of legislation, such as increasing the minimum taxable income in the 2009 Income Tax Law.

With these increased responsibilities, many in Vietnam are concerned that VNA delegates may not be up to the tasks of crafting complex legislation or overseeing increasingly specialized bureaucracies. Former National Assembly chairman Nguyễn Văn An (2007), among others, noted that the quality of legislation and oversight is lacking, citing as an example the fact that many delegates, particularly highranking party members, fail to speak during the query sessions. Other research has also found that more than 60 percent of delegates failed to speak during the first four sessions of the Twelfth National Assembly, and less than half offered any comments that could be deemed critical (Malesky and Schuler 2010).

These criticisms have led to debate within Vietnam about the best way to induce delegates to more actively fulfill their duties, such as speaking in hearings or asking questions during query sessions. On one side of the debate, some commentators suggest that the problem is that of technical expertise, which leads them to favor strengthening the current system of preplanning an ideal assembly and then vetting candidates to ensure that only appropriate delegates are elected. Those supporting this point of view also favor legislating formal education requirements for the delegates. One of the most prominent advocates of this approach is Bùi Ngọc Thanh (2009), chairman of the National Election Board (Ban Bầu cứ) in 2007, who argues that formal education standards are necessary for the VNA to legislate and oversee the bureaucracy in increasingly complex issue 
areas. From this perspective, opening up candidacy to anyone increases the risk that voters may select incompetent delegates (Đố Ngọc Hải 2009).

Similarly, another group, while not explicitly opposing the current system, believes that the targets set prior to the elections do not include enough full-time delegates and nonparty members. The problem is not that delegates are not qualified, but instead that the VNA is filled with part-time delegates who are required, in many cases, to criticize the same bureaucracies where they hold full-time positions. Former delegate Nguyễn Ngọc Trân noted that there are many competent, locally nominated part-time delegates who are afraid to assert themselves for fear of jeopardizing state resources for their province. ${ }^{3}$ The problem is not only with local officials. As Nguyễn Văn An (2007) noted in his essay on his vision for the VNA, many senior party leaders for obvious reasons are loath to scrutinize high-ranking state officials, most of whom are also top-level party members. From the perspective of these critics, an important solution is to decrease the number of part-time delegates with positions elsewhere in the bureaucracy and to dramatically increase the number of full-time delegates. To that end, the 2001 Law on the Organization of the National Assembly mandated a minimum proportion of full-time delegates of about 25 percent.

While the previous arguments favor tinkering within the existing framework of preplanning the assembly, a final group argues that the current process of mandating qualifications and drawing up a blueprint for an ideal assembly needs to be discarded. In contrast to previous arguments, they define competence as a willingness to reflect the opinions and desires of the people, a quality that can only be maximized by liberalizing the electoral system. Therefore, they not only oppose legislating standards for candidates, they also favor relaxing the "three negotiations" ( $b a$ hiẹp thuong) vetting system, whereby the central and provincial party leaders preplan an ideal VNA based on demographic and occupational backgrounds before vetting individual candidates to achieve this target (Nguyễn Đăng Dung 2007). As Nguyễn Thị Phương (2010), a professor of law at Hanoi National University, wrote, "Legislating standards for VNA representatives is good, but it is better if the electoral system has a method of selecting high quality candidates based on choice." Vũ Văn Nhiêm (2010) suggests that one should not equate intellectuals (nhà trí thức) with politicians (nhà chính trị), and that if the politicians do not have the requisite expertise in a certain issue area, the correct response is not to legislate or preplan the VNA in a way that 
ensures the body contains representatives with those qualities. Instead, VNA delegates should be able to hire staff to help them in their duties.

Overarching this debate over the quality of delegates is a question of broader interest to foreign scholars of Vietnam and other authoritarian regimes, which is, how do we define the role of elections in authoritarian regimes such as Vietnam? Vietnam, unlike the other remaining countries with ruling Communist parties, uses competitive elections to fill its parliament. How do competitive elections facilitate or complicate regime goals? Scholars studying other authoritarian regimes have also posed this question and generated a substantial literature that theorizes about the potential benefits regimes might gain from conducting at least marginally competitive elections. ${ }^{4}$ This literature is largely a response to the realization that rather than destabilizing authoritarian regimes, as surmised by some (Huntington 1991), regimes with elections actually appeared to outlast those without them (Geddes 1999). Several causal mechanisms have been proposed. Some have suggested that elections provide a safety valve for opponents to express dissatisfaction (Sartori 1976), while others suggest that they deter opposition through a signal of overwhelming strength (Magaloni 2006). Finally, some argue that they provide information on regime/opposition strength, or identify important local notables (Boix and Svolik 2007) who may then be incorporated into the ruling elite (Gandhi and Przeworski 2006).

Students of Vietnam have also posed the question in terms of the VCP and the VNA. Gainsborough (2005) suggests that elections in Vietnam are an attempt to comply with global democratic norms. Lockhart (1997) theorizes that the VCP uses them to mobilize and consult with citizens in order to maintain the bond between the party and society. Thayer (2010) suggests that increased competition is a response to domestic critics who challenge the legitimacy of singleparty rule. Other work has examined the extent to which the VCP may use elections to gain information about the popularity and competence of local cadres (Malesky and Schuler 2009) and whether they use elections to co-opt potential opposition (Malesky and Schuler 2011). Finally, Salomon (2007) argues that VNA elections serve as "popularity contests," where citizens can punish venal cadres and identify potential rising stars.

Out of these theories, we focus on Salomon (2007) and Boix and Svolik's (2007) theory of elections as a mechanism for voters to select the most qualified and able representatives. We focus specifically on this question because of its relevance to the debate around 
how to improve the quality of the VNA. If they are right, perhaps the VNA is already using the electoral system to increase the competency of its membership above and beyond what it would be if it simply appointed the delegates, as is done in China. In response, we pose the following question: Do the formal steps taken to increase competition for VNA seats reflect the VCP's desire to improve the legislature's capacity? On the surface, it would appear that there is some link between the competitiveness of the elections and a desire for a more accountable, qualified legislative body. Since 1992, along with the increase in power for the VNA, the VCP has also steadily increased the number of candidates per seat. The 2007 election featured their largest-ever total of 1.77 candidates per seat (see Figure 1).

Below, we test this theory using a unique dataset of biographical data from the 2007 election. However, before doing so we briefly discuss how theorists in democratic contexts suggest that competition improves representation and the quality of a legislature. We also introduce some of Vietnam's representative institutions that will be important for our empirical tests.

\section{A Theory of Elections in Vietnam}

In her seminal work on representation, Pitkin (1967) broke the concept down into its many uses in order to zero in on the meaning of

Figure 1 Candidates-to-Seat Ratios in VNA Over Time

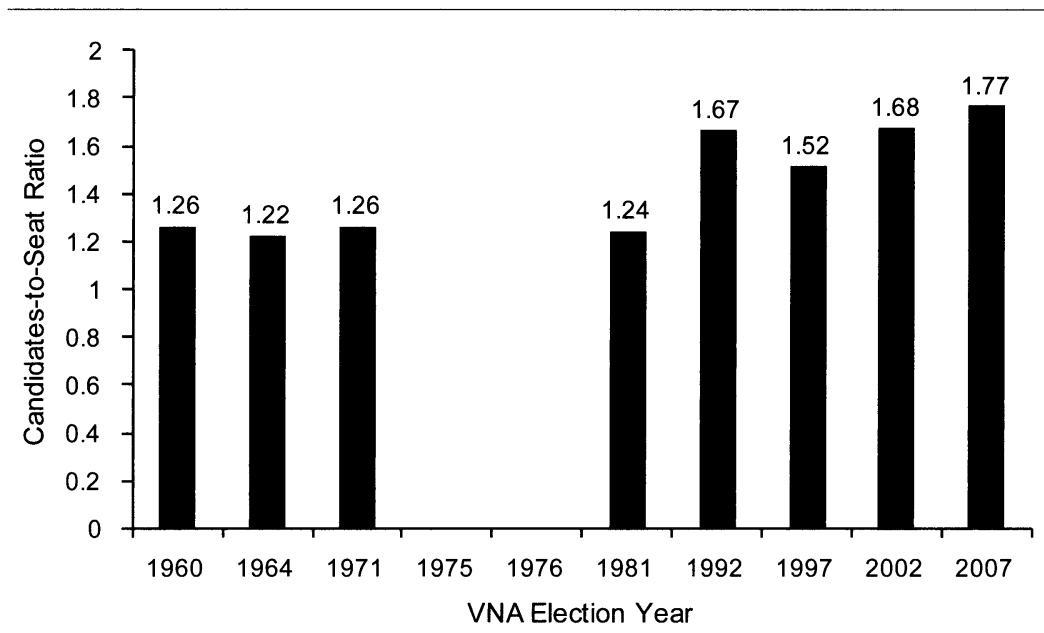


"representative government." In defending her view that political representation entails a "substantive acting for others" (Pitkin 1967, 167), she challenges the idea of "descriptive representation" where delegates are said to be representative if they share similar demographic characteristics, such as class, ethnicity, or career background. "Acting for" representation means that the representatives must promote and safeguard the interests of the constituents even when the constituents might not have enough information to make the correct decision themselves. While she acknowledges that having a similar background is certainly an important part of legitimizing a legislative body, relying solely on this basis of representation will fail to ensure that the assembly faithfully performs its role: "the best descriptive representative is not necessarily the best representative for activity or government" (Pitkin 1967, 89).

Even today, the VCP seems to base the legitimacy of the VNA on the concept of descriptive representation. After the first stage of vetting, which usually takes place about four months before election day, the government announces the proposed "structure" for the VNA (Hồng Khánh 2007; Nhân Dân 2007), which suggests how many women, ethnic minorities, businessmen, members of the Fatherland Front, and so on the regime wants in the final composition of the assembly. The VCP then highlights the percentage of seats these targeted groups won in announcing the final election outcome (Bùi Ngọc Thanh 2007). Critics of this system have voiced concerns similar to Pitkin's that preplanning a VNA that looks like Vietnamese society does not lead to an assembly willing to promote the interests of voters. While the VCP has resisted suggestions to do away with the preplanning of the assembly, they have conceded to increasing the number of candidates for seats. This, in theory, means that increased competition could be an effort to improve the quality of the VNA. Although a certain district may only be able to choose among ethnic minority candidates, the fact that they are given a choice could allow voters to identify a more capable delegate than if there were no choice.

How might competition lead to better representation? According to theories of elections, there are two general explanations. ${ }^{5}$ First, an election can be used as a mechanism for generating accountability, either between an individual legislator and his or her constituents or between a party and its supporters (Carey 2008). In this conception, voters vote retrospectively on the performance of their representative or the government, selecting the delegate or the party for reelection if they performed well and throwing them out if they underperformed. 
In the second conception, voters improve representation through elections by selecting the option they prefer from a menu of platforms. Assuming that the policy promises of the politicians are credible, the delegates then carry out those promises once elected. As campaigns are limited in Vietnam and there is little broad policy discussion, this view of elections does not likely apply to Vietnam. ${ }^{6}$ However, there is a variant of this view of elections that could be relevant. Elections can also be a way for voters to identify high-quality candidates who are presumed to be more likely to represent them once elected (Fearon 1999). These candidates may not make specific policy promises, but voters can use the information they have to sort out who is more honest or competent. Although accountability may play a role in providing some information as to whether that candidate will perform well in the future, this conceptualization of elections does not rely primarily on retrospective voting. Rather, voters attempt to distinguish a high-quality from a low-quality candidate, who will perform better regardless of whether that delegate will face electoral sanctions.

We explore the second conception as it could help explain how Vietnamese elections may lead to a more competent assembly. There are two reasons the logic of accountability is not a credible explanation for why the VCP conducts elections. First, and most obviously, because opposition parties are barred from running, the regime cannot use elections to create a sense of collective accountability of the VCP to the citizenry. Second, individual accountability to a constituency is also limited in Vietnam by the fact that more than 70 percent of delegates are not renominated by the VCP to run in subsequent elections, and many of those who are, run in different provinces. If the regime were concerned with using elections as a way to induce better performance among candidates through electoral accountability, the VCP would surely change these policies.

Because the logic of accountability does not apply, we focus on the second potential benefit provided by elections, which is that they allow local voters, who may have better information about the quality of the local candidates than regime officials, to select better-qualified representatives. This mechanism may apply, because not only do voters have some choice over candidates in the election, but at least hypothetically they are also involved in the nomination process. The Vietnamese vetting process is explained in detail elsewhere (Koh 2006; Malesky and Schuler 2009), but in brief the process entails three "negotiations," which are essentially meetings arranged by the Fatherland Front ${ }^{7}$ and the central and provincial election boards to set 
a structure for the assembly, decide on a preliminary list, and finalize the list. After the first negotiation, VCP and state agencies at all levels meet to nominate candidates whose names are submitted to the $\mathrm{Fa}$ therland Front for the second negotiation. In the second negotiation, a preliminary list of candidates is drawn up. After the second negotiation, the front arranges meetings with about fifty of the nominees' neighbors, where they vote on whether they support their nomination to the final ballot, which is decided upon at the third negotiation.

Of course, this process faces some limitations as a way of providing a genuine local perspective on the quality of the nominee. First, the meetings are only among fifty voters for candidates that have to represent on average 300,000 constituents. Second, based on interviews, attendees for these voter meetings are often selected carefully. This is done in several ways. First, the meetings are often scheduled during the workday when only retirees or party employees can attend. Second, sometimes only trusted party members are explicitly invited to the meetings. Finally, if the local party has enough control over the process, there is potential for top-down pressure to conform to the choices of the provincial bureaucratic apparatus that nominated the candidates.

However, while these factors may limit the ability of the constituents to have unvarnished input into the nomination process, it is important to note that these limitations are not altogether absent in democratic contexts where parties also have to rely on internal, and debatably undemocratic, methods to settle on a candidate. ${ }^{8}$ Indeed, relying on the local party officials to come to a consensus on a candidate is not vastly dissimilar to the use of the caucus in US primaries.

\section{Structure of the VNA}

How can one tell if the VCP is using elections to identify officials with the ability and willingness to actively represent constituents rather than to gain domestic or international legitimacy, obtain more information about the opposition, or signal strength to anyone thinking of challenging the regime? In terms of testing this proposition, we find that the extreme hierarchy within the VNA gives us a great deal of analytical leverage. If elections were used as a way to identify talent and improve the quality of the VNA leadership, then we should find that those who perform best in the elections are more likely to take over the all-important leadership roles within the VNA. Given the enormous power the leadership has vis-à-vis the part-time members in the lawmaking process and oversight, any serious attempt 
to use elections to bolster the quality of the assembly's activities would have to be reflected in an election's influence over leadership selection.

The VNA is an extraordinarily hierarchical institution. Although all assemblies feature some degree of hierarchy, with speakers or committee chairs afforded more power than other rank-and-file members, the VNA concentrates an extreme amount of power within its Standing Committee. The Standing Committee is comprised of the chairman of the National Assembly, four deputy chairpersons, and the chairs of the ten permanent committees as well as the head of the volunteer service, the head of legislative affairs, and the chairman of the Office of the National Assembly. Table 1 shows the committee breakdown of the VNA.

The Standing Committee is so important because the full body of the VNA only sits in Hanoi for two sessions per year, which last for about a month each. Therefore, between these sessions, the eighteenmember Standing Committee effectively takes over the VNA's legislative and oversight duties. In addition, the Standing Committee is largely responsible for setting the structure of the future and current VNA. After the first negotiation at the central level, it submits a blueprint for how the next VNA should be structured to the Fatherland Front, which is allowed to comment on it. Between the two

\section{Table 1 Committee Membership in the Twelfth Vietnamese National Assembly}

\begin{tabular}{lccc}
\hline & Leadership $^{\mathrm{a}}$ & Full-time & Part-time \\
\hline Standing Committee & 17 & $\mathrm{n} / \mathrm{a}$ & $\mathrm{n} / \mathrm{a}$ \\
Foreign affairs committee & 3 & 0 & 26 \\
Science, tech, and environment & & & \\
$\quad$ committee & 4 & 3 & 29 \\
Economic committee & 4 & 3 & 28 \\
Legislative committee & 4 & 3 & 26 \\
Law committee & 4 & 1 & 29 \\
Defense and security committee & 2 & 3 & 27 \\
Budget and finance committee & 4 & 2 & 28 \\
Culture, education, and youth & & & \\
$\quad$ committee & 4 & 3 & 31 \\
Social affairs committee & 4 & 1 & 34 \\
Ethnic affairs committee & 5 & 0 & 33 \\
No committee & $\mathrm{n} / \mathrm{a}$ & 0 & 128 \\
Total (out of 493 total delegates) & 55 & 19 & 419 \\
\end{tabular}

Notes: a. All committee chairs are also on the Standing Committee, so they are only counted in the Standing Committee. The leadership numbers include the deputy chairs. 
organizations, the Standing Committee appears to wield greater influence over how the body will be constructed. Once the structure is finalized, the Standing Committee can ensure that its blueprint is followed because many of its members also sit on the Central Election Board, a board created by the VNA Standing Committee to coordinate the nomination and vetting processes between the central and local levels. All local candidate lists must be sent to the Central Election Board for approval before the candidate slates are finalized.

Perhaps the greatest source of power for the Standing Committee versus the rest of the VNA is that it remains in Hanoi permanently, which gives it greater access to government officials and information. One other select group of delegates also enjoys this advantage. Each of the substantive committees has between three and five deputy chairpersons, who also remain in Hanoi. These deputy chairpersons are important because they work with the government law-drafting committees. In reality, what influence the VNA actually wields over legislation is almost entirely concentrated among the fifty-four chairpersons and deputy chairpersons of the ten committees (Harrington, McDorman, and Neilson 1998). The laws considered by the full VNA are largely the product of work conducted between government drafting committees and the permanent chairs and staff of the VNA committees.

Considering the importance of these delegates, it is critical to analyze how they are chosen. Answering this question will also provide clues to solving our puzzle about the role of elections in Vietnam. If the VCP in fact uses elections to identify talented delegates who can improve the quality of the VNA, then we should expect to see a relationship between election outcomes and leadership positions. We should expect to see those candidates who win a high percentage of the vote chosen for these leadership positions. Most of the government ministers are also selected from the VNA, so we should also expect the same logic to hold true for them. The candidates with the most support should be eventually incorporated into the highest circles of authority, thus sharing power in the autocracy. This leads to the following hypotheses.

H1: Vote share in the previous election should be positively correlated with the probability of receiving a VNA leadership position.

H2: Vote share in the previous election should be positively correlated with the probability of receiving a government ministerial appointment. 
However, an alternative hypothesis is that the regime preplans who these leaders are and simply uses the elections as a way of ratifying those it has already deemed "rising stars" through internal procedures. To lean on arguments made by those opposing more liberalized elections, fearing that voters will select incompetent candidates, the party identifies who is competent through its own internal vetting process. Because of observable variation in how the candidates are nominated, we can assess whether central regime leaders had more input into the nomination of certain candidates than voters or local party cells.

Candidates for the VNA are nominated and vetted at one of two levels. Candidates are either nominated centrally by national partystate organizations (such as the VCP, Prime Minister's Office, or military) before being vetted in meetings organized by the National Fatherland Front (VFF), or they are nominated and vetted by provincial officials. Once a final list of prescreened candidates is decided upon, the centrally nominated candidates are sent to compete in the provinces against the provincially nominated delegates (usually two to three) in multimember districts with bloc voting. ${ }^{9}$ The nomination status is important for the theory because if candidates are preselected for positions of authority within the VNA and in government regardless of the electoral outcome, this would suggest that the regime is using elections to ratify candidates it has already preselected for leadership roles rather than to identify them.

If procedures were used to identify and preselect rising stars, it is likely that the party would rely on central rather than provincial institutions to identify these delegates. This leads to the following alternative hypotheses:

Alternative H1: Central nomination is positively correlated with the probability of receiving a VNA leadership position. Alternative H2: Central nomination is positively correlated with the probability of receiving a government ministerial appointment.

\section{Methodology and Description of Variables}

We tested these hypotheses using candidate background data and election results from the 2007 VNA election. We combined this information with data we gathered from Vietnamese news sources and 
government Web sites regarding the positions the winning delegates took in the VNA after the elections. Below we will discuss our empirical strategy and our variables.

To test $\mathrm{H} 1$ and $\mathrm{H} 2$, we used two dependent variables. Upper leadership is a dichotomous variable indicating that the candidate was selected as a committee deputy chairman or a member of the VNA Standing Committee after the election. Government is a dummy variable denoting that the candidate was selected as a government minister after the 2007 election. Our key independent variable, Vote percentage, is the vote share the delegate received in the 2007 VNA election. To restate our hypotheses in terms of these variables, to confirm the predictions generated by the power-sharing model we would expect vote percentage to predict an increase in the likelihood of being selected for an upper leadership role within the VNA (H1) or as a government minister $(\mathrm{H} 2)$.

To test the alternative hypotheses that the regime uses internal procedures to select its leaders, we include a Centrally nominated variable, which is a dummy variable representing whether a candidate was nominated by a central party-state or a provincial organization.

We test both sets of hypotheses using the same general specification:

$$
y i=\beta_{0}+\beta_{I}(\text { percentage })_{i}+C_{l} X_{1 i}+C_{2} X_{2 i}+\varepsilon_{i}
$$

where $X_{1}$ is the matrix of candidate-level control variables and $X_{2}$ is the matrix of provincial-level control variables. To address the possibility that the estimates for our key independent variables are biased by other potential predictors of leadership status, we include a battery of biographical and provincial controls that could drive both vote share and the likelihood of selection. These include biographical variables, such as Age, Male, Religion, and education (Degree). Because most VCP officials do not adhere to an organized religion, we code Religion as a simple dummy variable, where " 1 " indicates that the candidate follows a religion. We also include party status and whether or not the delegate has served on the VNA before. Finally, if a candidate is already an Incumbent minister in the government prior to election, this should increase his or her chances of being selected as a minister in the new administration.

It is also possible that provincial-level factors could confound our results. Perhaps certain regions, such as wealthier, southern provinces, are both more competitive and less likely to have their dele- 
gates incorporated into the ruling elite. As such, we include controls for region and provincial gross domestic product (GDP per capita). We also include a measure of the percentage the province receives from the central budget relative to the total amount of revenue that they generate through taxes and service fees levied on businesses and citizens within their borders (Central transfers/local revenue). Because the central budget is largely supported by a few wealthy provinces in the south, for many of the provinces this figure is high because they receive far more in transfers from the center than they take in. Transfers come in two forms: (1) Equalization grants to balance the difference between local expenditures and revenue; and (2) Block grants for national programs (environment, poverty alleviation) that are allocated based on formulas. Other provinces, such as Ho Chi Minh City, however, remit far more to the center than they receive in return.

Unfortunately, a few of the control variables and some of the province and electoral district dummy variables perfectly predict failure (lack of leadership appointments) in the dichotomous dependent variable. This is a well-known issue with dichotomous dependent variables, which is referred to statistically as separation and implies maximum likelihood estimates will tend to infinity and therefore are inestimable. Many approaches commonly employed to address separation can lead to biased results or compromised inferences. First, some scholars drop the offending observations, an approach automatically employed by most statistical programs. Thus, for instance, a province from which no candidates received leadership appointments, and therefore demonstrated no variation, would be dropped from the analysis. While this approach does not lead to bias, it does reduce degrees of freedom and efficiency. A second approach is to use a linear probability model, rather than probit or logit specifications, which comes at the cost of incorrectly predicting marginal probabilities of leadership appointment in the tails of the distribution. Third, some scholars drop the problematic variables, which can lead to bias on the coefficients of the remaining variables.

As an alternative, we employ a penalized logit developed in the field of biomedical statistics to address this problem (Firth 1993; Heinze and Schemper 2002). ${ }^{10}$ The method penalizes the log-likelihood with one-half of the logarithm of the determinant of the information matrix. This approach offers the most precise estimates of marginal probabilities and standard errors in the face of separation. ${ }^{11}$ The results are displayed in Table 2. 
Table 2 Penalized Logit Estimates of Selection into VNA Upper Leadership

\begin{tabular}{|c|c|c|c|c|c|c|c|c|}
\hline & \multicolumn{4}{|c|}{ Full Status } & \multicolumn{2}{|c|}{ Nomination Status } & \multicolumn{2}{|c|}{ Fixed Effects } \\
\hline & $\begin{array}{c}\text { Bivariate } \\
1\end{array}$ & $\begin{array}{c}\text { Demographic } \\
2\end{array}$ & $\begin{array}{c}\text { Political } \\
3\end{array}$ & $\begin{array}{c}\text { GDP } \\
4\end{array}$ & $\begin{array}{c}\text { Local } \\
5\end{array}$ & $\begin{array}{c}\text { Central } \\
6\end{array}$ & $\begin{array}{c}\text { Province } \\
7\end{array}$ & $\begin{array}{c}\text { District } \\
8\end{array}$ \\
\hline Vote percentage & $\begin{array}{l}0.0279 * * \\
(0.0134)\end{array}$ & $\begin{array}{c}0.0245 \\
(0.0156)\end{array}$ & $\begin{array}{c}-0.00387 \\
(0.0190)\end{array}$ & $\begin{array}{c}-0.00302 \\
(0.0196)\end{array}$ & $\begin{array}{c}-0.00523 \\
(0.0983)\end{array}$ & $\begin{array}{c}-0.00531 \\
(0.0201)\end{array}$ & $\begin{array}{c}0.0121 \\
(0.0293)\end{array}$ & $\begin{array}{l}0.00530 \\
(0.0356)\end{array}$ \\
\hline Age & & $\begin{array}{l}0.0508^{* *} \\
(0.0233)\end{array}$ & $\begin{array}{l}-0.0919 * * * \\
(0.0325)\end{array}$ & $\begin{array}{l}-0.0923 * * * \\
(0.0327)\end{array}$ & $\begin{array}{c}0.0465 \\
(0.0849)\end{array}$ & $\begin{array}{l}-0.104 * * * \\
(0.0353)\end{array}$ & $\begin{array}{l}-0.109 * * \\
(0.0448)\end{array}$ & $\begin{array}{c}-0.0388 \\
(0.0509)\end{array}$ \\
\hline Male dummy & & $\begin{array}{c}0.435 \\
(0.443)\end{array}$ & $\begin{array}{c}0.805 \\
(0.573)\end{array}$ & $\begin{array}{c}0.816 \\
(0.572)\end{array}$ & $\begin{array}{l}-0.282 \\
(1.855)\end{array}$ & $\begin{array}{c}0.779 \\
(0.594)\end{array}$ & $\begin{array}{c}0.951 \\
(0.677)\end{array}$ & $\begin{array}{c}0.392 \\
(0.583)\end{array}$ \\
\hline Minority dummy & & $\begin{array}{c}0.341 \\
(0.458)\end{array}$ & $\begin{array}{c}0.135 \\
(0.630)\end{array}$ & $\begin{array}{c}0.139 \\
(0.671)\end{array}$ & $\begin{array}{c}0.856 \\
(1.724)\end{array}$ & $\begin{array}{c}0.184 \\
(0.693)\end{array}$ & $\begin{array}{c}-0.338 \\
(0.729)\end{array}$ & $\begin{array}{l}-0.513 \\
(0.857)\end{array}$ \\
\hline Religion dummy & & $\begin{array}{l}-0.493 \\
(0.976)\end{array}$ & $\begin{array}{c}1.093 \\
(1.139)\end{array}$ & $\begin{array}{c}1.073 \\
(1.143)\end{array}$ & $\begin{array}{c}1.415 \\
(2.073)\end{array}$ & $\begin{array}{c}1.266 \\
(1.247)\end{array}$ & $\begin{array}{c}1.000 \\
(1.341)\end{array}$ & $\begin{array}{c}1.206 \\
(2.299)\end{array}$ \\
\hline Degree (1 HS to 5 professor) & & $\begin{array}{l}0.488^{* * *} \\
(0.148)\end{array}$ & $\begin{array}{c}0.0166 \\
(0.191)\end{array}$ & $\begin{array}{c}0.0185 \\
(0.190)\end{array}$ & $\begin{array}{c}0.0567 \\
(0.881)\end{array}$ & $\begin{array}{c}0.0294 \\
(0.194)\end{array}$ & $\begin{array}{c}0.0363 \\
(0.243)\end{array}$ & $\begin{array}{c}-0.0191 \\
(0.319)\end{array}$ \\
\hline South & & $\begin{array}{c}0.276 \\
(0.331)\end{array}$ & $\begin{array}{c}0.0508 \\
(0.397)\end{array}$ & $\begin{array}{r}0.0279 \\
(0.410)\end{array}$ & $\begin{array}{c}-1.479 \\
(1.847)\end{array}$ & $\begin{array}{c}0.0698 \\
(0.422)\end{array}$ & & \\
\hline Incumbency (previous terms in VNA) & & & $\begin{array}{l}0.782 * * * \\
(0.227)\end{array}$ & $\begin{array}{l}0.772 * * * \\
(0.229)\end{array}$ & $\begin{array}{c}1.434 \\
(1.040)\end{array}$ & $\begin{array}{l}0.789 * * * \\
(0.240)\end{array}$ & $\begin{array}{l}0.923 * * * \\
(0.292)\end{array}$ & $\begin{array}{c}0.432 \\
(0.333)\end{array}$ \\
\hline Centrally nominated (dummy) & & & $\begin{array}{l}5.059 * * * \\
(0.917)\end{array}$ & $\begin{array}{l}5.036 * * * \\
(0.915)\end{array}$ & & & $\begin{array}{l}4.278 * * * \\
(0.866)\end{array}$ & $\begin{array}{l}2.394 * * * \\
(0.578)\end{array}$ \\
\hline GDP per capita (natural log) & & & & $\begin{array}{c}0.167 \\
(0.466)\end{array}$ & $\begin{array}{c}-1.806 \\
(2.418)\end{array}$ & $\begin{array}{c}0.263 \\
(0.468)\end{array}$ & & \\
\hline Central transfers/local revenue & & & & $\begin{array}{c}0.000388 \\
(0.00238)\end{array}$ & $\begin{array}{c}-0.0107 \\
(0.0150)\end{array}$ & $\begin{array}{c}0.000873 \\
(0.00242)\end{array}$ & & \\
\hline
\end{tabular}


Table 2 Continued

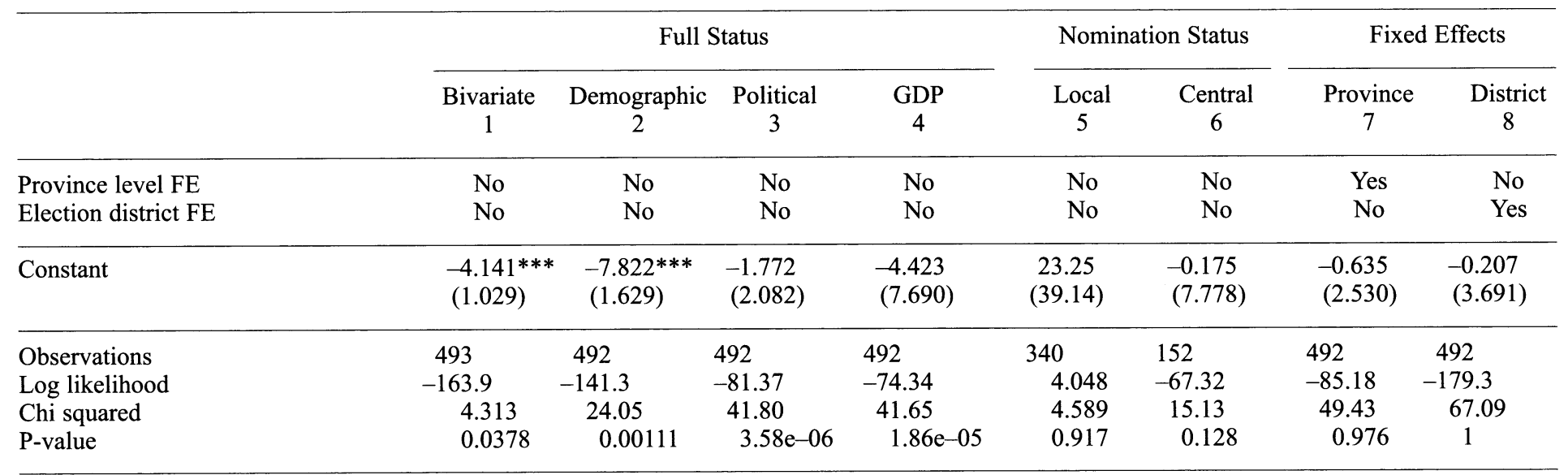

Notes: ${ }^{* *} p<0.05,{ }^{* *} p<0.01$. Implemented using firthlogit in STATA. Model 4 is the fully specified model, which is replicated in Model 5 for local nominees and Model 6 for central nominees. Logit estimates displayed with robust standard errors in parentheses. 
Tables 2 and 3 each contain eight models. In the first model we display the bivariate regressions. In Model 2, we add the basic set of candidate-level controls. Model 3 controls for nomination and incumbency status. Model 4 adds provincial-level control variables. Models 5 and 6 assess local and central nominees separately. Finally, Models 7 and 8 add provincial and electoral district fixed effects to ensure the results are not caused by unobserved heterogeneity at the regional level or electoral district level.

\section{Results}

The results for the upper leadership selections were conclusive. Although share of the vote is significant in the bivariate Model 1 , once we control for candidate qualities that might affect both vote share and leadership appointment, like education (Degree), the size of the coefficient on vote share declines toward zero. In subsequent models, Vote percentage was consistently insignificant in predicting whether a candidate would be selected for a leadership position in the VNA. Only two factors had robustly significant effects. Older candidates were less likely to be appointed to top leadership roles. Most important, however, was whether the candidate was centrally nominated. More precisely, central nomination gave candidates about a 35 percent greater chance of being selected to an upper leadership position. Other demographic characteristics also appeared to have little impact. Provincial characteristics were similarly indeterminate. In short, it would appear that being a central nominee is the clearest indicator that a particular candidate was destined for leadership. These nominations were decided months in advance of the election. Thus, performance in the election appears to be merely a means of legitimizing the regime's ultimate choices.

For government positions, the results were even more pronounced. Not a single government minister was selected from the ranks of the local nominees, leading to the problem of separation in the critical Centrally nominated variable. In other words, local nominees were perfectly associated with failure to achieve leadership positions. Thus, Table 3 shows penalized logit results on selection as a government minister. For the government leaders, we added a dummy for incumbent members of the government, because voters already knew those delegates would become government officials, which should have impacted the vote percentage they received.

As with leadership positions in the VNA, Vote percentage appears to be associated with appointment to a ministry until we control for 
Table 3 Penalized Logit Estimates of Selection into Government Ministerial Positions

\begin{tabular}{|c|c|c|c|c|c|c|c|c|}
\hline & \multicolumn{4}{|c|}{ Full Status } & \multicolumn{2}{|c|}{ Nomination Status } & \multicolumn{2}{|c|}{ Fixed Effects } \\
\hline & $\begin{array}{c}\text { Bivariate } \\
1\end{array}$ & $\underset{2}{\text { Demographic }}$ & $\begin{array}{c}\text { Political } \\
3\end{array}$ & $\begin{array}{c}\text { GDP } \\
4\end{array}$ & $\begin{array}{c}\text { Local } \\
5\end{array}$ & $\begin{array}{c}\text { Central } \\
6\end{array}$ & $\begin{array}{c}\text { Province } \\
7\end{array}$ & $\begin{array}{c}\text { District } \\
8\end{array}$ \\
\hline Vote percentage & $\begin{array}{c}0.170 * * * \\
(0.0364)\end{array}$ & $\begin{array}{c}0.0929 * \\
(0.0554)\end{array}$ & $\begin{array}{c}0.0686 \\
(0.0518)\end{array}$ & $\begin{array}{c}0.0716 \\
(0.0553)\end{array}$ & $\begin{array}{c}-0.00676 \\
(0.118)\end{array}$ & $\begin{array}{c}0.140^{* * *} \\
(0.0428)\end{array}$ & $\begin{array}{c}0.0439 \\
(0.0484)\end{array}$ & $\begin{array}{c}0.0180 \\
(0.0287)\end{array}$ \\
\hline Age & & $\begin{array}{l}0.103 \\
(0.0668)\end{array}$ & $\begin{array}{c}0.107 \\
(0.0814)\end{array}$ & $\begin{array}{c}0.0826 \\
(0.0828)\end{array}$ & $\begin{array}{c}0.0235 \\
(0.0869)\end{array}$ & $\begin{array}{c}0.0838 \\
(0.0580)\end{array}$ & $\begin{array}{c}0.0318 \\
(0.0604)\end{array}$ & $\begin{array}{c}0.0168 \\
(0.0335)\end{array}$ \\
\hline Male dummy & & $\begin{array}{c}-0.496 \\
(1.046)\end{array}$ & $\begin{array}{c}-0.260 \\
(1.074)\end{array}$ & $\begin{array}{c}-0.473 \\
(1.090)\end{array}$ & $\begin{array}{c}-0.564 \\
(1.802)\end{array}$ & $\begin{array}{c}0.407 \\
(0.902)\end{array}$ & $\begin{array}{c}-0.544 \\
(0.953)\end{array}$ & $\begin{array}{c}-0.154 \\
(0.513)\end{array}$ \\
\hline Minority dummy & & $\begin{array}{c}0.581 \\
(1.048)\end{array}$ & $\begin{array}{c}1.708 \\
(1.278)\end{array}$ & $\begin{array}{c}2.058 \\
(1.391)\end{array}$ & $\begin{array}{c}-0.184 \\
(2.548)\end{array}$ & $\begin{array}{c}0.226 \\
(1.128)\end{array}$ & $\begin{array}{c}1.341 \\
(1.345)\end{array}$ & $\begin{array}{c}0.484 \\
(0.682)\end{array}$ \\
\hline Religion dummy & & $\begin{array}{c}0.304 \\
(2.021)\end{array}$ & $\begin{array}{c}-0.578 \\
(2.058)\end{array}$ & $\begin{array}{l}-0.235 \\
(2.137)\end{array}$ & $\begin{array}{c}2.630 \\
(2.426)\end{array}$ & $\begin{array}{c}-1.352 \\
(2.148)\end{array}$ & $\begin{array}{c}-0.225 \\
(1.946)\end{array}$ & $\begin{array}{c}-0.557 \\
(1.393)\end{array}$ \\
\hline Degree (1 HS to 5 professor) & & $\begin{array}{c}0.544 \\
(0.332)\end{array}$ & $\begin{array}{c}0.428 \\
(0.356)\end{array}$ & $\begin{array}{c}0.381 \\
(0.367)\end{array}$ & $\begin{array}{c}0.309 \\
(0.941)\end{array}$ & $\begin{array}{c}0.267 \\
(0.244)\end{array}$ & $\begin{array}{c}0.293 \\
(0.371)\end{array}$ & $\begin{array}{c}0.151 \\
(0.264)\end{array}$ \\
\hline South & & $\begin{array}{c}-0.415 \\
(0.975)\end{array}$ & $\begin{array}{l}-0.496 \\
(1.025)\end{array}$ & $\begin{array}{c}-0.562 \\
(1.034)\end{array}$ & $\begin{array}{c}-0.329 \\
(2.361)\end{array}$ & $\begin{array}{c}-0.262 \\
(0.693)\end{array}$ & & \\
\hline Incumbent minister & & $\begin{array}{l}6.333^{* * * *} \\
(1.600)\end{array}$ & $\begin{array}{l}5.701^{* * * *} \\
(1.570)\end{array}$ & $\begin{array}{l}5.993 * * * \\
(1.731)\end{array}$ & & & $\begin{array}{l}4.071^{* * *} \\
(1.308)\end{array}$ & $\begin{array}{l}3.015^{* * * *} \\
(0.992)\end{array}$ \\
\hline Incumbency (previous terms in VNA) & & & $\begin{array}{c}-0.606 \\
(0.558)\end{array}$ & $\begin{array}{c}-0.557 \\
(0.538)\end{array}$ & $\begin{array}{c}0.679 \\
(1.246)\end{array}$ & $\begin{array}{c}-0.273 \\
(0.363)\end{array}$ & $\begin{array}{c}-0.208 \\
(0.543)\end{array}$ & $\begin{array}{c}-0.147 \\
(0.332)\end{array}$ \\
\hline Centrally nominated (dummy) & & & $\begin{array}{c}2.935^{*} \\
(1.545)\end{array}$ & $\begin{array}{c}2.859 * \\
(1.539)\end{array}$ & & & $\begin{array}{c}1.112 \\
(0.737)\end{array}$ & $\begin{array}{c}0.324 \\
(0.492)\end{array}$ \\
\hline GDP per capita (natural log) & & & & $\begin{array}{c}-1.274 \\
(1.738)\end{array}$ & $\begin{array}{c}1.678 \\
(1.627)\end{array}$ & $\begin{array}{c}0.943 \\
(0.703)\end{array}$ & & \\
\hline Central transfers/local revenue & & & & $\begin{array}{c}-0.00817 \\
(0.00708)\end{array}$ & $\begin{array}{c}0.00922 \\
(0.0110)\end{array}$ & $\begin{array}{c}-0.000333 \\
(0.00318)\end{array}$ & & \\
\hline
\end{tabular}




\section{Table 3 Continued}

\begin{tabular}{|c|c|c|c|c|c|c|c|c|}
\hline & \multicolumn{4}{|c|}{ Full Status } & \multicolumn{2}{|c|}{ Nomination Status } & \multicolumn{2}{|c|}{ Fixed Effects } \\
\hline & $\begin{array}{c}\text { Bivariate } \\
1\end{array}$ & $\begin{array}{c}\text { Demographic } \\
2\end{array}$ & $\begin{array}{c}\text { Political } \\
3\end{array}$ & $\begin{array}{c}\text { GDP } \\
4\end{array}$ & $\begin{array}{c}\text { Local } \\
5\end{array}$ & $\begin{array}{c}\text { Central } \\
6\end{array}$ & $\begin{array}{c}\text { Province } \\
7\end{array}$ & $\begin{array}{l}\text { District } \\
8\end{array}$ \\
\hline Province level FE & No & No & No & No & No & No & Yes & No \\
\hline Election district FE & No & No & No & No & No & No & No & Yes \\
\hline Observations & 493 & 492 & 492 & 492 & 340 & 152 & 492 & 492 \\
\hline Log likelihood & -57.47 & -18.22 & -13.70 & -7.363 & 7.663 & -25.57 & -53.59 & -168.2 \\
\hline Chi squared & 21.74 & 24.79 & 23.01 & 24.56 & 3.767 & 17.01 & 34.05 & 34.27 \\
\hline P-value & $3.12 \mathrm{e}-06$ & 0.00168 & 0.0107 & 0.0171 & 0.957 & 0.0741 & 1.000 & 1 \\
\hline
\end{tabular}

Notes: ${ }^{*} p<0.1,{ }^{* *} p<0.05,{ }^{* *} p<0.01$. Implemented using firthlogit in STATA. Model 4 is the fully specified model, which is replicated in Model 5 for local nominees and Model 6 for central nominees. Logit estimates displayed with robust standard errors in parentheses. 
Centrally nominated status. Once that variable is added in Model 3, the relationship between vote share and appointment disappears.

Probing more deeply, however, we analyze local and central nominees separately in Models 5 and 6. As is expected (after all, no local nominees became ministers), the coefficient is virtually zero for local nominees in Model 5. For central nominees in Model 6, however, there is a surprise. The coefficient on Vote percentage is statistically significant and substantively important. Each one percentage point in vote share increases the probability of government appointments for central nominees by 7 percent. That is, among the centrally nominated candidates, those who went on to become government ministers did appear to win a higher vote share than other centrally nominated candidates. This could provide some evidence that the regime uses the elections as a way to select ministers.

However, before reaching this conclusion, two caveats are in order. First, as mentioned above, none of the provincially nominated delegates was selected as a government minister. This suggests that the regime had already whittled the number of candidates for government positions from the total 876 candidates for the VNA, to the 156 they nominated centrally. Second, among the 156 central nominees, evidence from other work shows that the Vietnamese regime tends to engage in some preelectoral institutional manipulation, allowing it to secure victory by wide margins for its preferred candidates. Malesky and Schuler (2011) show that the regime relied on two key mechanisms to ensure larger margins of victory for preferred candidates.

First, the government allowed central nominees to run in districts with fewer candidates. Because of the bloc voting system, different electoral districts had different probabilities of victory. In the easiest districts, there were five candidates for three seats. In others, however, there were four candidates for two seats or six candidates for three seats, each mathematically more difficult than the five-for-three districts. However, a t-test shows that within the category of central nominees, the regime did not appear to favor government officials with mathematically easier districts. ${ }^{12}$

The second method was to place candidates in districts with weaker competition. Malesky and Schuler (2011) developed a metric to estimate the difficulty of the district by creating an additive index, wherein each candidate of the district was given a point if he or she was a member of the Politburo, a member of the Central Committee, a Provincial People's Committee chairman, a member of the People's Council, or a central nominee. A candidate's electoral difficulty 
was the sum of the power rankings of the other candidates in the district. ${ }^{13}$

Analysis shows that candidates who became government ministers did not appear to gain any substantive advantages that were not available to other centrally nominated candidates. While centrally nominated candidates were more likely to face weaker challengers, they, unlike members of the Politburo, were not substantially more likely to be placed in mathematically easier districts. Government ministers had these same advantages, but, critically, no additional advantage.

This analysis allows us to conclude that unlike upper-level leaders in the VNA, government ministers did appear to exhibit significantly more popularity than other centrally nominated leaders, which suggests that popular support may have played some role in their selection. However, this conclusion is limited by the fact that unlike the vast majority of the candidates, none of the government ministers was nominated locally, which means that the regime places severe limitations on the significance of public input.

\section{Internal Selection Methods}

While the previous analysis rules out vote share as a determinant of quality, it offers very little insight into why regime authorities nominated particular candidates in the first place. One concern is that central nominees may have been chosen due to their expected popularity with Vietnamese citizens that would translate directly into vote share. An alternative possibility is that loyalty matters more than expected popularity for authoritarian leaders. Consequently, the reason we do not observe a relationship between vote share and appointment is because top VNA candidates and ministers were selected due to their perceived loyalty to the regime.

Based on the data, we can see that those who were selected as full-time delegates and leaders within the VNA were significantly more educated than the other elected delegates. In fact, central nominees as a whole were far more educated than local nominees; 54 percent of central nominees had advanced degrees, compared to 20.5 percent of local nominees. This suggests that the VCP at least uses observable indicators of quality in their selection process.

Despite the fact that central nominees were more educated, the regime still may have chosen only loyal, educated elites. To analyze whether loyalty to the regime might be a factor in choosing whom to 
nominate as upper-level leaders, we looked at the behavior of those candidates selected for VNA leadership in the assembly. Assessing the party's selection criteria via postelection behavior is not as optimal as if we had information on the preelection behavior of all potential candidates given that performance may be endogenous to their leadership status. While we do have information on potential candidates for a subset of self-nominated delegates, which we will discuss below, given the absence of such data for the entire range of candidates, examining their behavior can still provide important insights. If behavior is in fact endogenous to their leadership status, this at the very least suggests that the leaders who are chosen are pliant when it comes to the wishes of the regime.

Using data collected to analyze the legislator activity for the 20072011 session of the VNA in previous work (Malesky and Schuler 2010), we assessed whether the upper-level leaders participated differently than other delegates in the biannual VNA query sessions. In the query sessions, legislators can grill sitting ministers on their performance, which on occasion has led to the ouster of certain poorperforming ministers. For the query sessions, we coded not only the quantity of questions but also the degree of criticism they levied against the ministers. The criticism variable is a simple count variable, indicating the number of times a delegate criticized the minister, ministry, or Vietnamese government. ${ }^{14}$

If legislators were chosen for their loyalty, we would expect them to be reluctant to challenge sitting members of the government, most of whom are also on the all-important Communist Party Central Committee. Models 1 and 2 in Table 4 assess whether VNA leaders were less likely to speak or engage in critical questioning of government ministers, controlling only for features of individual delegates. Models 3 and 4 add controls for characteristics of the province that the delegate nominally represents. Models 5 and 6 add controls for full-time members and centrally nominated members. It is important to note that nearly all members of the upper leadership are also centrally nominated full-time members, so to assess the substantive impact of being an upper leader one must include all of these variables to assess the net effect for leaders.

The results indicate that relative to the rest of the VNA, the members of the upper leadership were not substantially different in their willingness to speak. Again, while the impact of being a leader is negatively correlated with speaking, because all leaders are also full-time delegates, this negative impact is canceled out by the positive effect 
of being a full-time delegate. Therefore, the leaders are not substantially different from the rest of the assembly.

However, relative to other full-time members, they were far less willing to speak. Given that these full-time delegates have the most information concerning the activity of the government, this strong difference is important. In essence, in terms of activity the upper leadership in the VNA is more similar to the part-time delegates from the provinces that only spend two months of the year in Hanoi than it is to the other eighty-nine full-time members of the VNA. Given the significant power invested in these leaders and the resources at their disposal, this difference is surprising.

As mentioned above, we do not have data on the initial pool of candidates for the field. However, we do have data on a subset of candidates who self-nominated. Since 1992, the VCP has allowed for self-nomination as an additional channel to win nomination outside of traditional selection by a party, state, or officially sanctioned civil society institution. Although these candidates can freely throw their names into the hat, the process is not as open as it seems-once the candidates self-nominate they are subject to the same vetting procedures as the institutionally nominated candidates. This vetting process drastically reduced the number of candidates selected through this channel. In 2007, 236 self-nominees submitted CVs, but only 30 made it onto the ballot. Of those, only one managed to win election. ${ }^{15}$

While strictly controlled, this institution nonetheless gives us another window into the process the regime uses in selecting candidates. Although we do not have a list of all 236 self-nominees who submitted their CVs to provincial election boards across the country, we were able to obtain a list of the 101 candidates who self-nominated in Ho Chi Minh City. Of those 101 candidates, only 7 made it through the entire vetting process and were selected to the final ballot (all lost after their nomination). For the self-nominees, we have information on whether they were party members, age, ethnicity, gender, and career. As a further test of whether loyalty may have been an important factor in selection, we simply assessed whether party status was an important factor in their selection. The results were conclusive: party membership was the strongest predictor of selection to the ballot.

Although only 12 of the 101 (12 percent) self-nominees were party members, they made up 3 of the final 7 winning nomination (48 percent). As Figure 2 shows, controlling for a range of biographical variables, party members had a 50 percent probability of winning nomination, while nonparty members had a roughly 3 percent chance. ${ }^{16}$ 
Table 4 Participation in VNA Query Sessions/Debates

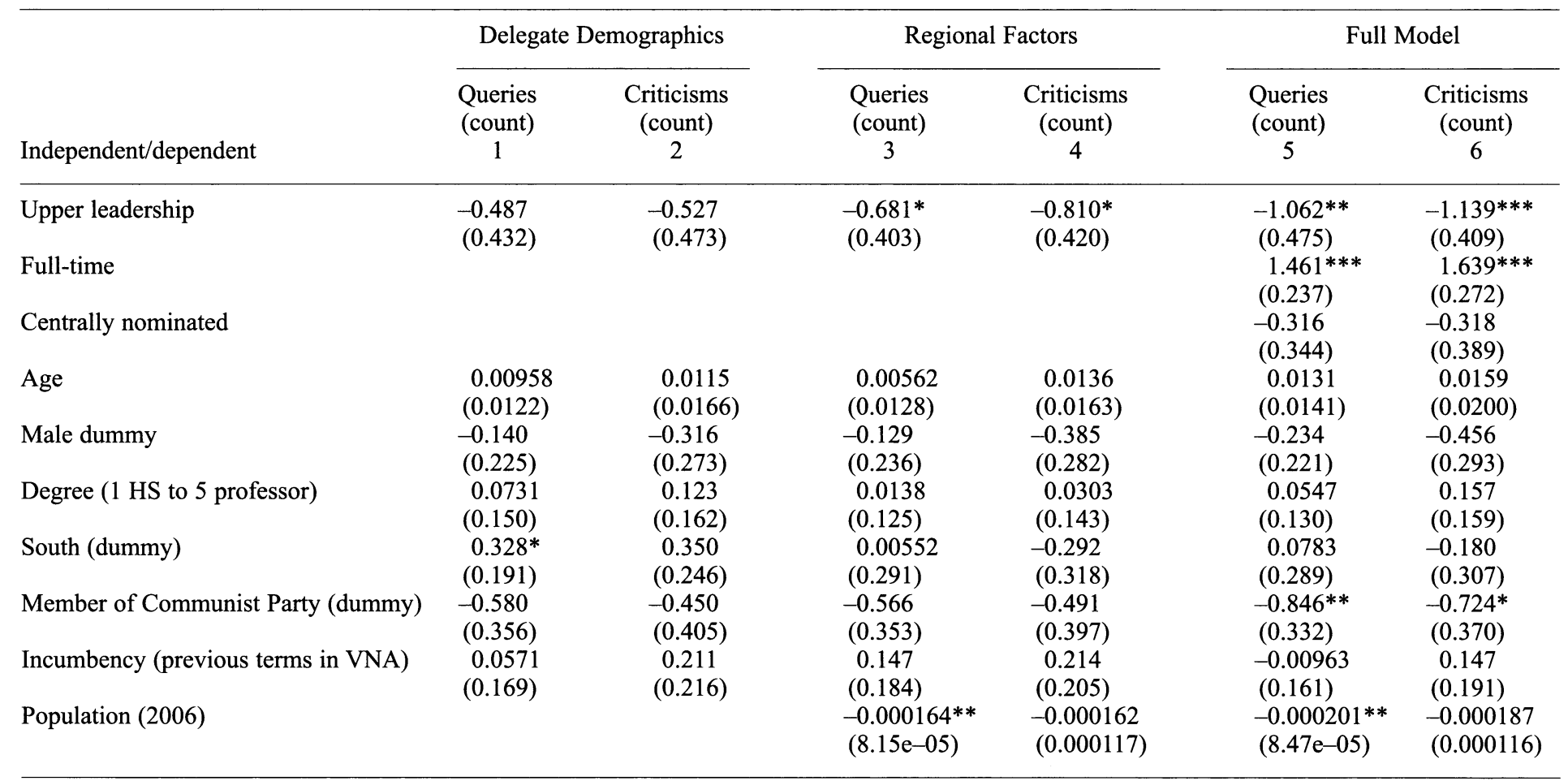


Table 4 Continued

\begin{tabular}{|c|c|c|c|c|c|c|}
\hline \multirow[b]{2}{*}{ Independent/dependent } & \multicolumn{2}{|c|}{ Delegate Demographics } & \multicolumn{2}{|c|}{ Regional Factors } & \multicolumn{2}{|c|}{ Full Model } \\
\hline & $\begin{array}{c}\text { Queries } \\
\text { (count) } \\
1\end{array}$ & $\begin{array}{c}\text { Criticisms } \\
\text { (count) } \\
2\end{array}$ & $\begin{array}{c}\text { Queries } \\
\text { (count) } \\
3\end{array}$ & $\begin{array}{c}\text { Criticisms } \\
\text { (count) } \\
4\end{array}$ & $\begin{array}{c}\text { Queries } \\
\text { (count) } \\
5\end{array}$ & $\begin{array}{c}\text { Criticisms } \\
\text { (count) } \\
6\end{array}$ \\
\hline Central transfer/provincial revenue & & & $\begin{array}{l}-0.00555^{* * *} \\
(0.00133)\end{array}$ & $\begin{array}{l}-0.00740 * * * \\
(0.00148)\end{array}$ & $\begin{array}{l}-0.00571 * * * \\
(0.00142)\end{array}$ & $\begin{array}{l}-0.00694 * * * \\
(0.00167)\end{array}$ \\
\hline Secondary school education & & & $\begin{array}{l}-0.0113 \\
(0.0257)\end{array}$ & $\begin{array}{c}-0.0398 \\
(0.0271)\end{array}$ & $\begin{array}{l}-0.0143 \\
(0.0259)\end{array}$ & $\begin{array}{l}-0.0392 \\
(0.0263)\end{array}$ \\
\hline Career fixed effects & Yes & Yes & Yes & Yes & Yes & Yes \\
\hline Constant & $\begin{array}{c}-0.332 \\
(1.425)\end{array}$ & $\begin{array}{l}-1.283 \\
(1.485)\end{array}$ & $\begin{array}{c}1.859 \\
(2.784)\end{array}$ & $\begin{array}{c}3.817 \\
(2.963)\end{array}$ & $\begin{array}{c}1.409 \\
(2.820)\end{array}$ & $\begin{array}{c}2.785 \\
(2.897)\end{array}$ \\
\hline lnalpha & $\begin{array}{l}1.534^{* * * *} \\
(0.110)\end{array}$ & $\begin{array}{l}1.638 * * * \\
(0.132)\end{array}$ & $\begin{array}{l}1.480^{* * *} \\
(0.106)\end{array}$ & $\begin{array}{l}1.539 * * * \\
(0.126)\end{array}$ & $\begin{array}{l}1.358 * * * \\
(0.108)\end{array}$ & $\begin{array}{l}1.348 * * * \\
(0.146)\end{array}$ \\
\hline $\begin{array}{l}\text { Observations } \\
\text { Chi-squared } \\
\text { Log likelihood }\end{array}$ & $\begin{array}{c}492 \\
3633 \\
-861.0\end{array}$ & $\begin{array}{c}492 \\
3623 \\
-506.4\end{array}$ & $\begin{array}{c}492 \\
4999 \\
-861.0\end{array}$ & $\begin{array}{c}492 \\
6854 \\
-506.4\end{array}$ & $\begin{array}{c}492 \\
3558 \\
-861.0\end{array}$ & $\begin{array}{c}492 \\
3769 \\
-506.4\end{array}$ \\
\hline
\end{tabular}

Notes: ${ }^{*} p<0.1,{ }^{* *} p<0.05,{ }^{* * *} p<0.01$. Negative binomial estimation employed with standard errors clustered at the province level. 
Figure 2 Probability of Self-Nominees' Surviving Vetting (by party membership)

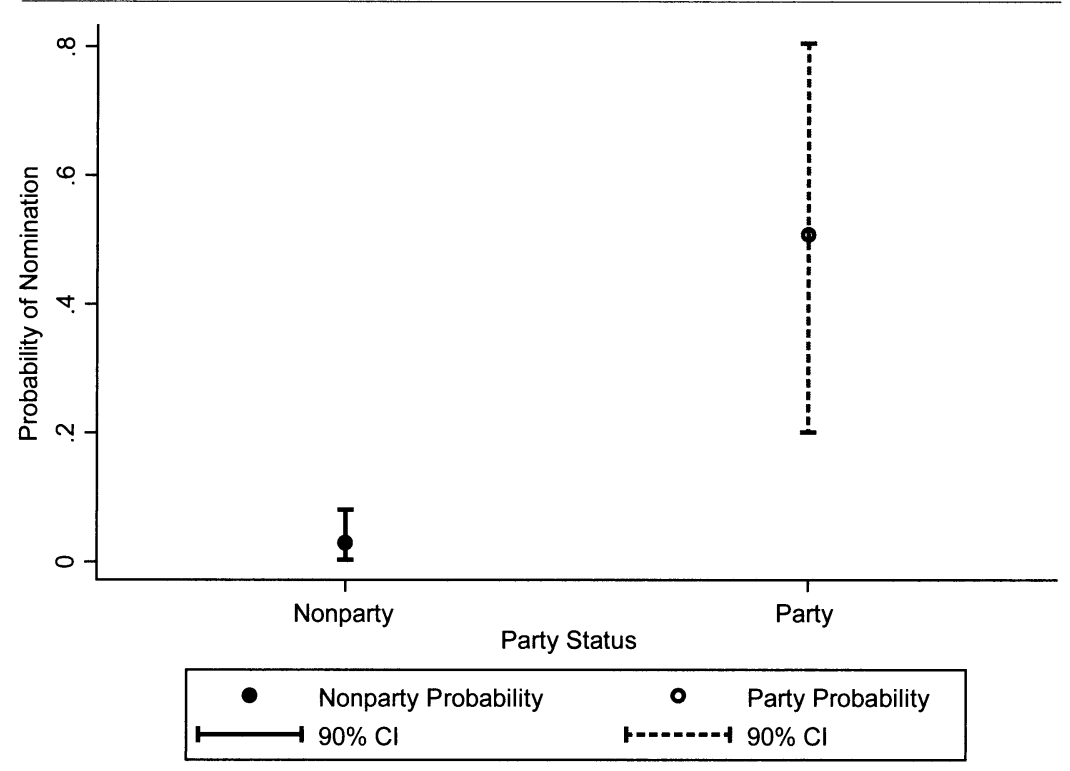

Note: These estimates and confidence intervals are based on a Clarify simulation of 1,000 estimates of the multivariate probit model. Controls included education, age, religion, minority status, and whether the candidate is an entrepreneur or local government official. All controls are held constant at the mean.

Because there were so few party members who self-nominated and because the estimate is near 50 percent, the standard error on the estimate for the party member is quite large. However, even so, it does not overlap with the estimate for the nonparty members, indicating a significant difference in the likelihood of selection for party members. Taken together, these findings provide strong evidence that loyalty is a key concern in terms of the internal selection process.

\section{Conclusion}

The results of our statistical analysis show that vote share is not a factor in leadership selection. The Vietnamese regime does not appear to take the results of the election into account before promoting certain delegates to all-important leadership positions at the central level. Instead, the results indicate conclusively that the leaders are largely predetermined prior to the election, and that loyalty to the regime is an important contributing factor in this internal selection 
process. This finding supports evidence from interviews conducted for previous work (Malesky and Schuler 2009) that suggests officials from the ONA actually contact potential leaders for the VNA prior to nominating them for office. These delegates are also usually nominated at the central level, which our results confirm.

On the surface, evidence from Vietnam could point to support for aspects of another candidate selection model. Boix and Svolik (2011) suggest that when leaders need more cooperation from society, either because of less ability to rely on natural resources or because of a cut in international support for regime leaders, they strengthen the role of the assemblies. Boix and Svolik (2011) test the model by showing that authoritarian regimes relied more heavily on assemblies after the end of the Cold War because the United States and the Soviet Union were no longer propping up dictatorships. Indeed, the collapse of the Soviet Union led to a drastic reduction in foreign aid, which was a major factor leading to the creation of the 1992 Vietnamese constitution. A key component of the 1992 constitution was to strengthen and clarify the role of the VNA by developing standing committees and allowing more full-time delegates. Based on these results, it seems that the regime is trying to increase the technical expertise and legitimacy of VNA delegates by preselecting experts and having the public ratify them rather than allowing local notables to reveal themselves. This reflects the viewpoint espoused by the secretary of the Central Election Board, Bùi Ngọc Thanh, that increased competition is inimical to generating a competent assembly.

If the increased competition is not a way of improving the performance of the VNA, then we still face the question of the purpose the elections serve and why the VCP has slowly increased the competition for seats. Our evidence most strongly supports Thayer's (2010) suggestion that increased competition is a concession to demands from civil society for political reform. However, if this is the goal, it is not clear that the limited steps taken to increase competition have had the desired results. Indeed, as Thayer himself has noted, proponents of democratization have not been quelled by the regime's liberalization of the assembly. Quite the contrary, groups such as Bloc 8406 and Viet Tan, which sponsored a course in nonviolent opposition attended by recently jailed lawyer Lê Công Đinh, seem to have expanded and stepped up their coordination (Mydans 2010). It is unlikely that changes to the electoral code will satisfy these critics as long as Article 4 of the constitution continues to maintain that the Communist Party is the country's sole political force.

If this theory is correct, then is liberalization of the elections simply part of a failing strategy? As argued elsewhere, the regime 
could be deriving other benefits from fielding a greater number of candidates (Malesky and Schuler 2009). First, more open elections could allow the VCP to gain information on the popularity of its cadres as well as information on its level of administrative control. By observing the electoral outcomes, the regime can assess whether certain cadres are abnormally unpopular and use this information either to weed them out or to improve their performance. There is some evidence that the regime actually requires candidates who are members of the Central Committee who win with less than 60 percent of the vote to undergo self-criticism (Salomon 2007). Public protests such as the demonstrations in Thai Binh in 1997 and the Central Highlands in 2001 could have prompted the VCP to have greater demand for such information on the performance of local cadres. In addition to information about individual cadres, the VCP may also want information on how well local administrative agencies are carrying out the edicts of the central government. In a country where local officials are notorious for either stretching or outright flouting central initiatives (Fforde and de Vylder 1996; Malesky 2008), such information may be valuable.

Edmund Malesky is associate professor of political economy at Duke University. He has published in leading political science and economic journals, including the American Political Science Review and Journal of Politics, and has been awarded the Harvard Academy Fellowship and Gabriel Almond Award for best dissertation in comparative politics. Malesky serves as the lead researcher for the Vietnam Provincial Competitiveness Index and is a noted specialist in political development in Vietnam and China, comparative political economy in Southeast Asia, as well as economic transitions in developing economies. He can be contacted at ejm5@duke.edu.

Paul Schuler is a PhD candidate at the University of California-San Diego. $\mathrm{He}$ has published articles in the American Political Science Review, Legislative Studies Quarterly, and other regional journals.

\section{Notes}

1. For a debate on how best to improve delegate quality, see a series of debates in the Tạp Chí Nghiên Cứu Lập Pháp (Journal of Legislative Studies) (Vũ Văn Nhiêm 2010; Nguyễn Thị Phương 2010; Bùi Ngọc Thanh 2009; Đỗ Ngọc Hải 2009).

2. This view of the assembly was confirmed in more recent interviews conducted in fieldwork for Malesky and Schuler (2009).

3. Nguyễn Đặng Tấn, "Chất lượng Quốc hội, chất lượng phát triển," TuanVietnam.Net, May 19, 2009, http://community.tuanvietnam.net/chat -luong-quoc-hoi-chat-luong-phat-trien?print=1. Accessed November 16, 2012. 
4. For a review of this literature see Gandhi and Lust-Okar (2009).

5. A deeper discussion of this topic can be found in Manin, Przeworski, and Stokes (1999).

6. Official candidate lists are usually drawn up only three weeks before election day, which gives candidates limited time to campaign. Furthermore, the VCP prohibits candidates from attacking other candidates in the same electoral district.

7. The Fatherland Front is the VCP's umbrella organization for Vietnam's main civil society groups, such as the Vietnamese Federation of Labor and the Communist Youth League.

8. For a review of internal party selection mechanisms in the West see Pennings and Hazan (2001).

9. Under the bloc vote electoral system each voter can cast a vote for as many delegates as there are seats assigned to that district.

10. In particular, we use the STATA command firthlogit developed by Joseph Coveney.

11. While marginal probabilities vary slightly in size, the core theoretical findings of the model do not differ greatly if we use linear probabilities models or logit when the offending variables are dropped. These alternative specifications are available upon request.

12. Central nominees who became government ministers were placed in districts with an average number of 1.83 candidates per seat, while others were placed in districts with 1.80 candidates per seat. The t-statistic from the test is -0.37 with a p-value of .352 .

13. Please see Malesky and Schuler (2011) for a further elaboration of the coding scheme. Power rankings range from zero to twelve. Central nominees who became government ministers faced competition with an average score of 3.33 , while those who did not faced competition with an average score of 3.73. The t-statistic from the test is 0.890 with a p-value of .80 .

14. For a more complete explanation of the data, please see Malesky and Schuler (2011).

15. For a fuller discussion of the self-nominated candidates, see Malesky and Schuler (2009).

16. Controls included education, age, religion, minority status, and whether the candidate is an entrepreneur or local government official. All controls are held constant at the mean. We include the table for this regression on our dataverse site (www.thedata.org).

\section{References}

Boix, Carles, and Milan Svolik. 2007. "Non-tyrannical Autocracies.” Manuscript. 2011. "The Foundations of Limited Authoritarian Government: Institutions and Power-sharing in Dictatorships," September 24. http:// ssrn.com/abstract=1352065 or http://dx.doi.org/10.2139/ssrn.1352065.

Bùi Ngọc Thanh. 2007. "Những kết quả chủ yếu của cuộc bầu cử đại biểu Quốc hội khóa XII." Tạp chi Công sản 10:130. www.tapchicongsan 
.org.vn/details.asp?Object $=17556103 \&$ news_ID $=30539481$ (accessed July 19, 2010).

ـ 2009. "Về việc sửa đổi, bổ sung Luật Bầu cử đại biểu Quốc hội." Tạp Chí Nghiên Cứu Lập Pháp, December 10, 160.

Carey, John. 2008. Legislative Voting and Accountability. New York: Cambridge University Press.

Đỗ Ngọc Hải. 2009. "Về tiêu chí đại biểu Quốc hội trong điều kiện Việt Nam là thành viên WTO." Tạp Chí Nghiên Cúu Lập Pháp, December 10, 160.

Fearon, James. 1999. "Electoral Accountability and the Control of Politicians: Selecting Good Types Versus Sanctioning Poor Performance." In Democracy, Accountability, and Representation, ed. Adam Przeworski, Susan Stokes, and Bernard Manin, 55-97. New York: Cambridge University Press.

Fforde, Adam, and Stefan de Vylder. 1996. From Plan to Market: The Economic Transition in Vietnam. Boulder, CO: Westview Press.

Firth, David. 1993. "Bias Reduction of Maximum Likelihood Estimates." Biometrika 80, 1: 27-38.

Gainsborough, Martin. 2005. "Party Control: Electoral Campaigning in Vietnam in the Run-up to the May 2002 National Assembly Elections." Pacific Affairs 78, 1: 57-75.

Gandhi, Jennifer, and Ellen Lust-Okar. 2009. "Elections Under Authoritarianism." Annual Review of Political Scienc. 12: 403-422.

Gandhi, Jennifer, and Adam Przeworski. 2006. "Cooperation, Cooptation, and Rebellion Under Dictatorships." Economics and Politics 18, 1: $1-26$.

- 2007. "Authoritarian Institutions and the Survival of Autocrats." Comparative Political Studies 40, 1: 1279-1301.

Geddes, Barbara. 1999. "Authoritarian Breakdown: Empirical Test of a Game Theoretic Argument." Paper presented for the Annual Meeting of the American Political Science Association, Atlanta.

—. 2006. "Why Parties and Elections in Authoritarian Regimes." Revised version of paper presented at the Annual Meeting of the American Political Science Association, Washington, D.C., August 2005.

Gillespie, John. 2008. "Localizing Global Rules: Public Participation in Lawmaking in Vietnam." Law and Social Inquiry 33, 3: 673-707.

Harrington, Joanna, Ted McDorman, and William Neilson. 1998. "The 1992 Vietnamese Constitution: Economic Reform, Political Continuity." In Asia-Pacific Legal Development, ed. Douglas Johnston and Gerry Ferguson, 243-266. Vancouver: UBC Press.

Heinze, Georg, and Michael Schemper. 2002. "A Solution to the Problem of Seperation in Logistic Regression." Statistics in Medicine 21, 16: 2409-2419.

Hồng Khánh. 2007. "Sẽ giảm thành viên Chính phủ là đại biểu Quốc hội" [The National Assembly will reduce the delegates from the government]. VnExpress, February 23. http://vnexpress.net/Vietnam/Xa-hoi/2007/02/ 3B9F3731/ (accessed November 9, 2007). 
Huntington, Samuel. 1991. The Third Wave: Democratization in the Twentieth Century. Norman: University of Oklahoma Press.

Koh, David. 2006. Wards of Hanoi. Singapore: Institute of Southeast Asian Studies.

Lockhart, Greg. 1997. "Mass Mobilization in Contemporary Vietnam." Asian Studies Review 21, 2: 174-179.

Magaloni, Beatriz. 2006. Voting for Autocracy. New York: Cambridge University Press.

Malesky, Edmund. 2008. "Straight Ahead on Red: How Foreign Direct Investment Empowers Subnational Leaders." Journal of Politics 70, 1: 97-119.

Malesky, Edmund, and Paul Schuler. 2009. "Paint-by-Numbers Democracy: The Stakes, Structure, and Results of the 2007 Vietnamese National Assembly Election." Journal of Vietnamese Studies 4, 1: 1-48.

—. 2010. "Nodding or Needling: Analyzing Delegate Responsiveness in an Authoritarian Parliament." American Political Science Review 104, 3 (August): 1-21.

- 2011. "The Single-party Dictator's Dilemma: Information in Elections Without Opposition." Legislative Studies Quarterly 36, 4: 491-530.

Manin, Bernard, Adam Przeworski, and Susan Stokes. 1999. "Introduction." In Democracy, Accountability, and Representation, ed. Adam Przeworski, Susan Stokes, and Bernard Manin, 1-26. New York: Cambridge University Press.

Mydans, Seth. 2010. "Vietnam, Quelling Dissent, Gives 4 Democracy Advocates Jail Terms." New York Times, January 20.

Nguyễn Đăng Dung. 2007. Ý Tưởng: Về Một Nhà Nước Chịu Trách Nhiệm. Nhà Xuất Bản Đa Nẵng. Da Nẵng.

Nguyễn Thị Phương. 2010. "Có nên bằng cấp hóa tiêu chuẩn đại biểu Quốc hội?" Tạp Chí Nghiên Cưu Lập Pháp 167 (March 20): 6.

Nguyễ் Văn An. 2007. "Thực hành dân chủ trong hoạt động của Quốc hội" [Realizing democracy in the activity of the National Assembly]. Vietnamnet (March 20). www.vietnamnet.vn/chinhtri/doinoi/2007/03/675344/ (accessed January 11, 2010).

Nhân Dân. 2007. "Tăng đại biểu chuyên trách, giảm đại biểu là thành viên Chính phủ" [The National Assembly will increase the full-time delegates and decrease the government delegates], February 24. Người Đại Biểu. www.nguoidaibieu.com.vn/Trangchu/VN/tabid/66/CatID/1/Content ID/8155/Default.aspx (accessed November 25, 2007).

Pennings, Paul, and Reuven Hazan. 2001. "Democratizing Candidate Selection: Causes and Consequences." Party Politics 7, 3: 267-275.

Pitkin, Hannah. 1967. The Concept of Representation. Berkeley: University of California Press.

Reuter, Ora John, and Rostislav Turovsky. 2011. "Dominant Party Rule and Legislative Leadership in Authoritarian Regimes." SSRN. http://papers .ssrn.com/sol3/papers.cfm?abstract_id=1972859 (accessed September 21, 2012). 
Salomon, Mathieu. 2007. "Power and Representation at the Vietnamese National Assembly: The Scope and Limits of Political Doi Moi." In Vietnam's New Order, ed. Stephanie Balme and Mark Sidel, 198-216. New York: Palgrave Macmillan.

Sartori, Giovanni. 1976. Parties and Party Systems: Volume 1. New York: Cambridge University Press.

Shih, Victor, Christopher Adolph, and Mingxing Liu. 2012. "Getting Ahead in the Communist Party: Explaining the Advancement of Central Committee Members in China. American Political Science Review 106, 1: $166-187$.

Thayer, Carlyle. 2010. "Political Legitimacy in Vietnam: Challenge and Response." Politics and Policy 38, 3: 423-444.

Vasavakul, Thaveeporn. 2002. "Rebuilding Authority Relations: Public Administration in the Era of Doi Moi." Manila: Asian Development Bank.

Vietnam Development Report. 2010. "Modern Institutions.” A Joint Donor Report to the Vietnam Consultative Group Meeting, December 2-4, 2009. www.presscenter.org.vn/en//images/WBreport2010.pdf (accessed July 20, 2010).

Vũ Văn Nhiêm. 2010. "Bàn thêm về chủ đề 'Có nên bằng cấp hóa tiêu chuẩn đại biểu Quốc hội?" Tạp Chi Nghiên Cưu Lập Pháp. www.nclp.org .vn/ban-doc-viet/ban-them-ve-chu-111e-201cco-nen-bang-cap-hoa-tieuchuan-111ai-bieu-quoc-hoi-201d. 